RESEARCH ARTICLE

\title{
THE IMPLEMENTATION OF DISASTER MANAGEMENT AND LEGAL PROTECTION FOR DISASTER RELIEF VOLUNTEERS (CASE OF CENTRAL JAVA PROVINCE, INDONESIA)
}

\author{
Hilda Maulida \\ Postgraduate Program, Master of Laws, Universitas Negeri Semarang, Indonesia \\ $\triangle$ maulidahilda45@gmail.com
}

\section{CITED AS}

Maulida, H. (2020). The Implementation of Disaster Management and Legal Protection for Disaster Relief Volunteers (Case of Central Java Province, Indonesia). Journal of Law and Legal Reform, 1(3), 415-424. DOI: https://doi.org/10.15294/jllr.vli3.36702

\section{ABSTRACT}

Regulation of the Head (Perka) of the National Disaster Management Agency (BNPB) Number 17 of 2011 concerning the Disaster Management Voluntary Guidelines which in addition to being a volunteer guideline also regulates voluntary obligations and rights. Of the three volunteer rights contained in the Perka, there is one volunteer right that is not explained in detail, namely the volunteer's right to get legal protection in the implementation of disaster management tasks. This study uses a qualitative research approach, a type of juridical-sociological research, the focus of research on legal protection for disaster relief volunteers in carrying out disaster management tasks, research locations in the Regional Disaster Management Agency (BPBD) of Central Java Province, primary and secondary data sources, and uses interactive analysis models. The implementation of disaster management in Central Java Province BPBD and the form of legal protection for disaster relief volunteers in the implementation of disaster management tasks in Central Java Province BPBD. The implementation of disaster management tasks in the Central Java Province BPBD is guided by three stages, namely the pre-disaster stage, the emergency response stage, and the post-disaster stage. While the form of legal protection for disaster relief volunteers in the implementation of disaster management tasks in BPBD Central Java Province in the form of physical, psychological, and mental health insurance during carrying out disaster management activities.

Keyword: Protection; Disaster Management; Volunteer; Legal Protection 


\section{TABLE OF CONTENTS}

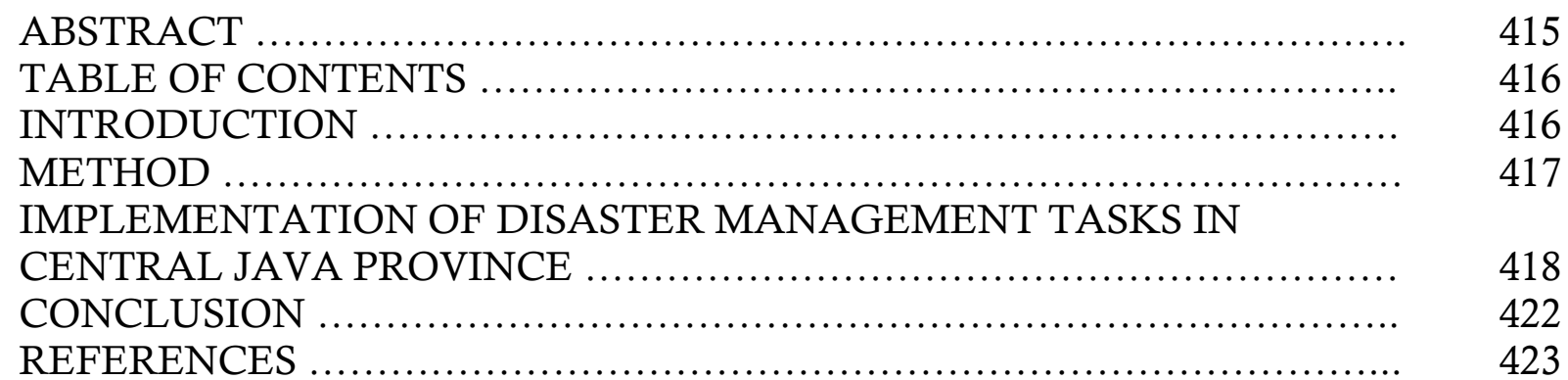

\section{INTRODUCTION}

Indonesia is a country with a large population. Indonesia is a country that is prone to disasters, at the same time Indonesia has great human resource potential, which can be empowered in the face of emergencies and in disaster risk reduction efforts. Natural disasters are also a threat that cannot be predicted by all countries. Every country, both poor countries, developing countries and developed countries can also face the threat of disaster (Herningtyas, 2014). Natural disasters have an impact high fatalities in the world, especially in vulnerable groups, one of them with disabilities (Novalita, 2018). Disaster Management in Indonesia is regulated in Law Number 24 Year 2007, the law stipulates that the government and regional governments are responsible for carrying out disaster management.

The researcher made Central Java Province the focus of this research. Central Java Province is the focus of this study because based on the Disaster Risk Index Data (IRBI) issued by the National Disaster Management Agency (BNPB) in 2013, Central Java Province has a score of 158 with a high ratio class. From these data shows that Central Java Province has a high potential for disaster. The high potential of the disaster makes Central Java Province which is divided into 35 regencies and cities and has a population of approximately $32,000,000$ people, indicating that in addition to having high disaster potential, Central Java Province also has great potential for disaster relief volunteers. Individual preparedness is inseparable from the role of government in efforts to improve community preparedness (Utomo, Muryani, \& Nugraha, 2018). This is evidenced by the many voluntary organizations in Central Java which include Central Java SARDA (Central Java Regional SAR), Central Java Muhammadiyah Disaster Management Center, Central Java TAGANA (Disaster Preparedness), UBALOKA (Scout Aid Unit) in Java Central and many other voluntary organizations. 
The volunteers must first understand their rights and obligations. These matters are contained in the Head of Regulation (Perka) of the National Disaster Management Agency No. 17 of 2011 concerning Guidelines for Disaster Volunteer Management. The regulation included the role of volunteers in disaster management, volunteer data collection, volunteer training, volunteer deployment, and monitoring and evaluation. The disaster relief volunteer in this party is defined as a person or group of people who have the ability and concern to work voluntarily and sincerely in disaster management efforts. The regulation was made so that the involvement of stakeholders could be directed, coordinated, and protected by their legal rights. The regulation states that the rights of volunteers include obtaining recognition and identification of volunteers for disaster management, getting capacity building related to disaster management, and getting legal protection in the implementation of disaster management tasks. However, in the regulation there is no clause that clearly discusses what legal protection volunteers obtain in carrying out their disaster management tasks (Arifin, 2020; Arifin \& Lestari, 2019).

\section{METHOD}

This research uses legal research with a qualitative legal research approach. The definition of legal qualitative research is research that is actually a research procedure that produces descriptive data, i.e. what is stated by the respondent in writing or verbally, and real behavior. The thing that is studied and studied is a whole object of research, as long as it concerns humans. Thus, by using a qualitative approach, a researcher primarily aims to understand or comprehend the symptoms being examined (Soekanto, 2012; Arifin, Waspiah, \& Latifiani, 2019).

This type of research is sociological-juridical. The focus of research on the implementation of disaster management tasks is based on the Central Java Province Regional Regulation No. 11 of 2009 concerning the Implementation of Disaster Management in Central Java Province and the form of legal protection for disaster relief volunteers in the implementation of disaster management tasks in the Regional Disaster Management Agency (BPBD) of Central Java Province. The data source uses primary and secondary data sources with data collection techniques in the form of library studies, interviews, observations, and documentation. Data validity with data triangulation techniques and data analysis using interactive analysis models. 


\section{IMPLEMENTATION OF DISASTER MANAGEMENT TASKS IN CENTRAL JAVA PROVINCE}

The implementation of disaster management tasks in the Regional Disaster Management Agency (BPBD) of Central Java Province is regulated in the Central Java Provincial Regulation No. 11/2009 concerning the Implementation of Disaster Management in Central Java Province. BPBD is a Regional Disaster Management Agency that is engaged in Disaster Management (PB) in the Region, which is meant by the Region in this case namely the Provincial Government and Regency and City Governments. While the Central Java Province BPBD is a Disaster Management Agency / Agency that operates in the Central Java Provincial Government, the basis of its initial formation was based on the Minister of Home Affairs Regulation No. 46 of 2008, and strengthened by the Head of BNPB (Perka) Regulation No. 3 of 2008 concerning Guidance for Establishment Regional Disaster Management Agency, Regional Regulation Number 10 of 2008, Regional Regulation Number 101 of 2008, and Regional Regulation Number 11 of 2009 concerning Disaster Management in Central Java Province.

To anticipate the potential and high occurrence of disasters in Central Java, the Provincial Government of Central Java has issued several regulations in the field of disaster management, including:

1. Regional Regulation (Perda) of Central Java Province Number 10 of 2008 concerning Organizations and Work Procedures of Other Regional Institutions of Central Java Province;

2. Regional Regulation Number 11 of 2009 concerning Implementation of Disaster Management in the Central Java Region;

3. Central Java Governor Regulation (Pergub) Number 101 of 2008 concerning the Explanation of the Main Tasks, Functions and Work Procedures of the Secretariat of the Regional Disaster Management Agency (BPBD) of Central Java Province;

4. Decree of the Governor of Central Java Number 120/42/2010 concerning the Establishment of the Regional Disaster Management Steering Element for the Central Java Province 2010-2015.

The implementation of disaster management has been guided by the three main stages of disaster management, as stated on Art. 33 Law No. 24 of 2007 concerning Disaster Management, namely:

1. Pre-disaster stages;

2. Stages at the time of the disaster (emergency response), and;

3. Stages after a disaster. 
Implementation of the three main stages of the implementation of disaster management in its journey there are still many obstacles encountered so that it has not yet maximized what has become the ideals of the mandate of Law Number 24 Year 2007 and the wishes of the community. Each of these stages disaster relief volunteers are always involved.

Disaster Management Volunteers, hereinafter referred to as volunteers, are a person or group of people, who have the ability and concern in disaster management who work sincerely for disaster management activities (Perka BNPB No. 1 of 2011). Volunteers work based on Pancasila and the 1945 Constitution. Volunteers also have work principles in their duties, namely: fast and precise, priority, coordination, efficient and efficient, transparency, accountability, partnerships, empowerment, nondiscrimination, not spreading religion, gender equality, and respect for local wisdom.

To be able to realize its performance well, disaster management volunteers have five darma (actions) called the Panca Darma Disaster Management Volunteers in disaster management efforts as stipulated on Chapter 1 Perka BNPB No. 1 of 2011 concerning Guide for Volunteer of Disaster Management Task, namely:

1. Independent, during the assignment of disaster management, volunteers must be able to take care of themselves and not bother or burden others,

2. Professional, disaster management volunteers must be able to work professionally according to their capacity and competence,

3. Solidarity, disaster management volunteers must be able to apply and uphold the values of solidarity and social solidarity,

4. Synergy, disaster management volunteers must be able to work together and work well together and support each other as a team to realize comprehensive and integrated services in accordance with applicable mechanisms and regulations, and

5. Accountable, disaster management volunteers must be able to demonstrate accountability for their performance, which can be ethically and legally accountable.

Furthermore, Chapter II Perka BNPB No. 1 of 2011, emphasized that when disaster does not occur, volunteers can play a role in disaster risk reduction or mitigation and training activities. Disaster risk reduction or mitigation activities include organizing joint trainings with the community, providing information to the community, providing information to increase community awareness in the context of disaster risk reduction, and increasing community awareness. The Chapter III also highlighted that while the intended training includes basic/advanced management training, disaster technical training, rehearsal and disaster simulation.

During an emergency response, volunteers can assist in the rapid assessment of the coverage of the affected area, the number of victims and damage, the need for 
resources, the availability of resources as well as the prediction of future situation development; search, rescue and evacuate residents affected by the disaster; provision of public kitchens; fulfillment of basic needs in the form of clean water, clothing, food, and health services including environmental health; provision of temporary shelter (huntara); protection of vulnerable groups by giving priority to services; emergency repairs / restoration for the smooth supply of basic needs to disaster victims; provision of information systems for handling emergencies; psychosocial assistance for disaster victims; other activities related to social, cultural and religious affairs; and other activities related to emergencies. Post-disaster situations volunteers can assist in the collection and management of damage and loss data in the housing, infrastructure, social, economic and cross-sector sectors. Volunteers can also participate in physical and non-physical rehabilitation-reconstruction activities during the early recovery period (Aji, Wiyatno, Arifin, \& Kamal, 2020).

The deployment of volunteers is carried out in two stages: the preparation and deployment stages. There are two things to do when preparing for deployment, before deployment, and administrative equipment and supporting facilities for the assignment. Pre-deployment preparations are carried out by giving a brief description of the disaster area, the impact of the disaster, a map of the disaster location, the route of the trip or post, the evacuation route, the current situation, the length of time of the assignment, and the parties to be contacted for coordination; division of tasks according to their competence; completing the assignment facilities and infrastructure; volunteer health checking; periodic reporting of activities delivered to the commander; coordination and communication with related parties in the field by voluntary parent organizations; and evaluating the development of the situation every day with other volunteers or carrying out other humanitarian activities.

Administrative completeness that must be brought by volunteers is assignment letter, individual identification card, and Volunteer Member Card. During the emergency response, volunteers are provided with personal protective equipment (PPE) according to the type of disaster and the area of duty, and the completeness of the team as needed. Volunteers must also bring their own daily personal supplies.

The deployment is carried out after the preparatory phase is carried out. Mobilizing Regency / City and Provincial level volunteers with Provincial / District / City BPBD provides information to volunteer parent organizations about the needs of volunteers to be deployed / assigned in disaster management according to the needs at the disaster location. Provincial / district / city level supervisory institutions assign volunteers according to the criteria / skills and quantity needed at the disaster site. The guiding institution will immediately coordinate with user institutions / agencies and / or BPBDs that require volunteer support in relation to location, burden / job description and length of assignment. Control of activities in the field, from departure 
to the location of the assignment to repatriation, is always monitored by the supervisory agency. Each volunteer assigned must be responsible for carrying out their duties and submit reports in accordance with applicable regulations. The assignment of volunteers with the cooperation of institutions / agencies and other organizations must be through official letters. If deemed necessary, the assignment of volunteers can be ratified through a Letter of Agreement between the relevant institutions.

The volunteer mobilization mechanism is carried out through the community/ institution/agency in the disaster location in coordination with the regional BPBD regarding requests for volunteer support. BPBD submits / corresponds to the parent volunteer organization regarding the needs of the number of volunteers and details of the skills needed to be deployed to the disaster site. Furthermore, the parent volunteer organization verifies the needs of volunteers and completes administration on request. The parent volunteer organization hands over volunteers through the BPBD and / or directly through the Emergency Response Commander/Field Coordinator. Emergency Response Commander/Field Coordinator mobilizes volunteers at the disaster site based on the needs at the disaster site. The end of the volunteer task is adjusted to the request of the emergency response command, but it is also possible to provide support after an emergency situation. At the end of the task can be given guidance that can be done in the form of psychosocial program activities, dialogue or discussion, and health checks. Volunteers are required to make a report on the implementation of the task and submit it to the guiding institution and other relevant parties.

Form of Legal Protection for Voluntary Disaster Management in Central Java Province

Volunteer disaster management is technically under the Regency/City Government, while the Regional Government is limited to facilitating. Facilitating what is interpreted here is limited to mobilizing and controlling, not yet to the technical aspects of how volunteers' rights and obligations are and related to matters related to risk and so on. Whereas technical matters as mentioned earlier in the form of rights and obligations of volunteers and related risks and so on, each is attached to the Regency/City of Government but it is necessary to remember again that each Regency /City has different abilities.

Head of Regulation (Perka) of the National Disaster Management Agency No. 17 of 2011 concerning the Guidelines for Voluntary Disaster Management is mentioned about the rights and obligations of volunteers but in its implementation the Regional Government has no authority because the volunteers are owned by the Regency / City. The Regional Government is only limited as a coordinator not to form, but only to empower and facilitate in the form of providing training in collaboration with other agencies / institutions. Providing these trainings is important for volunteers because disaster relief volunteers need to have the skills or special skills needed in disaster management. When talking about the legal protection of volunteers who are 
volunteer rights that are in Perka BNPB Number 17 of 2011, we also talk about certification which shows that the volunteers have the skills to be able to participate in operational activities in disaster management tasks (Personal Interview, Zainuddin, 2017).

By law volunteers are social organizations. Until now in Central Java Province, there are no regulations, either Regional Regulations, Governor Regulations or other similar regulations that can actually support volunteers, and until now the existence of volunteers is independent. Although independent when in the field as Law Number 24 of 2007 concerning Disaster Management, that anyone who is in a disaster location must obey and comply with Government Regulation No. 21 of 2008 concerning the Implementation of Disaster Management that is regulated by the Regional / Regency / City Government. The issuance of the Head of the Regulation (Perka) of the National Disaster Management Agency No. 17 of 2011 concerning the Guidelines for Volunteer Disaster Management still raises doubts regarding the extent of the Head Regulation (Perka) of the National Disaster Management Agency whose status is at the ministerial level compared to other regulations which are both issued by the minister or ministerial level (Personal Interview, Purwito, 2017).

When an accident happens to volunteers in the implementation of disaster management the Regional Government continues to facilitate but has not been clearly regulated in a regulation, facilitating here is also only a form of concern. The Provincial Government is actually still difficult to form regulations that technically govern volunteers, because to be a volunteer is a group or individual initiative and must not sue. Even though in the field, when volunteers work for humanity, their existence will be guaranteed / protected by disaster management organizers, namely the Regional / Regency/City Government where the disaster is limited to being allowed to be involved in disaster activities.

The form of voluntary legal protection which is a volunteer right that is in Perka BNPB Number 17 of 2011 is in the form of physical and psychological health insurance during carrying out disaster management activities and life safety guarantees during carrying out disaster management activities from its development agency or the agency that assigns it.

\section{CONCLUSION}

Based on the results of research and discussion, it can be concluded that the implementation of disaster management tasks in the Regional Disaster Management Agency (BPBD) of Central Java Province is guided by three main stages, namely the pre-disaster stage, the stage during a disaster (emergency response), and the post- 
disaster stage. The pre-disaster phase includes situations where no disaster occurs and situations where there is a potential for disaster to occur. The stage at the time of the disaster (emergency response) which includes a rapid and precise assessment of the location, damage, and resources; determination of the status of a disaster emergency; rescue and evacuation of affected communities; fulfillment of basic needs; protection of vulnerable groups; and immediate recovery of vital infrastructure and facilities. The form of legal protection for volunteers is in the form of physical and psychological health insurance during carrying out disaster management activities and life safety guarantee during carrying out disaster management activities from its development agency or the agency that assigns it. The implementation of voluntary legal protection does not yet have a regulation that regulates technically and can be used as a legal basis. When an accident happens to volunteers in the implementation of disaster management, the organizer of disaster management in this case the local government, still facilitates, even though it has not been clearly stipulated in a regulation. Facilitating here is also only a form of care. Regional governments are actually still difficult to form regulations that technically govern volunteers, because to be a volunteer is a group or individual initiative and must not sue. Even though in the field, when volunteers work for humanity, their existence will be guaranteed / protected by disaster management organizers, namely the Regional / Regency / City Government where the disaster is limited to being allowed to be involved in disaster activities.

\section{REFERENCES}

Aji, A. B. W., Wiyatno, P., Arifin, R., \& Kamal, U. (2020). Social Justice on Environmental Law Enforcement in Indonesia: The Contemporary and Controversial Cases. The Indonesian Journal of International Clinical Legal Education, 2(1), 57-72. https://doi.org/10.15294/ijicle.v2il.37324.

Arifin, R., Waspiah, W., \& Latifiani, D. (2019). Penulisan Karya Ilmiah untuk Mahasiswa Hukum. Semarang: BPFH UNNES.

Arifin, R. (2020). Legal Protection and Law Enforcement: The Unfinished Works. Indonesian Journal of Advocacy and Legal Services,2(1), 1-4. https://doi.org/10.15294/ijals.v2il.38035

Arifin, R., \& Lestari, L.E. (2019). Penegakan dan Perlindungan Hak Asasi Manusia di Indonesia dalam Konteks Implementasi Sila Kemanusiaan yang Adil dan 
Beradab. Jurnal Komunikasi Hukum (JKH) 5(2), 12-25. DOI: http://dx.doi.org/10.23887/jkh.v5i2.16497.

BNPB. (2014). IRBI Indeks Risiko Becana Indonesia Tahun 2013. Jakarta: Direktorat Pengurangan Risiko Bencana Deputi Bidang Pencegahan dan Kesiapsiagaan.

Herningtyas, H. (2014). Disaster Management as a Soft Power in Indonesian Diplomacy. Journal of International Relations 3(1), 85-92.

Novalita, N. (2018). Cilacap State Special School (SLB) Preparedness in Dealing with Disasters in Cilacap Regency. Journal of Health Education 3(2), 75-85.

Personal Interview. (2017). Muhammmad Zainuddin, SHI as a staff of BPBD of Jepara Regency on Tuesday, April 11, 2017, at 09.00 WIB.

Personal Interview. (2017). Purwito, S.Pd as the Emergency Facilities and Infrastructure Section of the Disaster Management Agency (BPBD) of Central Java Province on Thursday 6 April 2017, at 09.00 WIB

Republic of Indonesia. (2007). Law Number 24 of 2007 concerning Disaster Management (Undang-Undang Nomor 24 Tahun 2007 tentang Penanggulangan Bencana).

Republic of Indonesia. (2009). Regional Regulation of Central Java Number 11 of 2009 concerning Implementation of Disaster Management in Central Java Province (Peraturan Daerah Provinsi Jawa Tengah Nomor 11 Tahun 2009 Tentang Penyelenggaraan Penanggulangan Bencana di Provinsi Jawa Tengah).

Republic of Indonesia. (2011). Regulation of Chief National Disaster Management Board Number 17 of 2011 concerning to Guide for Volunteer of Disaster Management Task (Peraturan Kepala Badan Nasional Penanggulangan Bencana Nomor 17 Tahun 2011 Tentang Pedoman Relawan Penanggulangan Bencana).

Soekanto, S. (2012). Pengantar Penelitian Hukum. Jakarta: UI Press.

Utomo, U., Muryani, M., \& Nugraha, N. (2018). Assessment of Tsunami Disaster Preparedness in Puring District Kebumen Regency 2016. GeoEco Journal 4(1), 6876. 